\title{
Changes in the Concentration of Trace Elements and Heavy Metals in El Chichón Crater Lake Active Volcano
}

\author{
Betsy Anaid Peña-Ocaña ${ }^{1}$, Irving Oswaldo Velázquez-Ríos ${ }^{1}$, \\ Rocío Jetzabel Alcántara-Hernández ${ }^{2}$, Cesar Ivan Ovando-Ovando ${ }^{1}$, \\ Reiner Rincón-Rosales ${ }^{1}$, Federico Antonio Gutiérrez-Miceli ${ }^{1}$, \\ Elizabeth González-Terreros ${ }^{3}$, Víctor Manuel Ruíz-Valdiviezo ${ }^{1 *}$
}

${ }^{1}$ Tecnológico Nacional de México / IT de Tuxtla Gutiérrez, Tuxtla Gutiérrez, Chiapas, México

${ }^{2}$ Instituto de Geología, Universidad Nacional Autónoma de México, Ciudad de México, México ${ }^{3}$ Instituto de Estudios Ambientales, Universidad de la Sierra Juárez, Ixtlán de Juárez, Oaxaca C.P. 6872, México

Received: 15 February 2020

Accepted: 26 April 2020

\begin{abstract}
The crater lake of El Chichón active volcano represents one of the most important extreme ecosystems in the world due to its high temperatures, low $\mathrm{pH}$ and the appearance of high concentrations of heavy metals because of volcanic activity. The latter is of great importance in nearby volcano sites due to heavy metal pollution, which is one of the worst types of environmental problems in the world. In this study, the concentration of heavy metals was evaluated in soils and sediments from different sections in the crater lake of El Chichón volcano. Representative samples were collected from four sediments and soils in 2015 and 2017. These samples were analyzed for 20 metals by inductively coupled plasma-optical emission spectrometry (ICP-OES). The most abundant elements in sediments of the crater lake of "El Chichón" volcano were $\mathrm{Fe}, \mathrm{Na}, \mathrm{Si}, \mathrm{Ca}, \mathrm{K}$ and $\mathrm{Al}$ and not found in soil samples. Be and $\mathrm{Tl}$ were more abundant in the soil, but the concentration of Se was higher in soil without showing statistically significant differences. Principal component analysis (PCA) showed that the abundance of metals was influenced by sample type. That is, a higher concentration of heavy metals and trace elements was found in volcanic sediments as compared to soil samples. This difference may be related to metals originating from the magma, which is partially transported in the water stream that gives way to the volcano lake. The most toxic heavy metals identified and quantified in high concentrations in crater soils and sediments were As and Cd. This study suggests that sediments and soils of El Chichón crater lake could be an important source of heavy metals and toxic elements such as As and Cd.
\end{abstract}

Keywords: active volcano, heavy metal toxicity, ICP-OES, extreme environmental, El Chichón volcano

*e-mail: bioqvic@hotmail.com 


\section{Introduction}

Volcanoes are a natural source of gases that gives shape to our atmosphere, and they are also extreme environments on Earth. They also emit gases (water, sulfur, and carbon), non-metallic elements, and volatile metals. These play an important role in volcanic activity, in the atmosphere and in microorganisms present in these geothermal systems [1]. The abundance of Heavy Metals (HM), high temperatures, and low nutrient bioavailability favor the development of microorganisms extremophiles [2].

The soil and sediments found in volcanic environments are basic components of biogeochemical systems. Microbial communities have been influenced by geochemical parameters in volcanic lakes, due to microorganisms interacting with the water and sediments $[3,4]$. Consequently, toxic components (e.g., heavy metals) can present levels of ecotoxicity and environmental hazards. In addition, these components interact in dissolution, absorption and desorption processes, causing an impact on the surrounding biological components, such as microorganisms and plants [3].

Mexico is one of the countries with the highest volcanic presence in the world, highlighting the presence of the Chiapanecan Volcanic Belt (CVB) [5-7]. El Chichón is an active volcano that belongs to the CVB. In 1982, El Chichón volcano presented the most important eruptive process in Mexican history [8], an eruption that resulted in the formation of a crater lake of $1.4 \times 10^{5} \mathrm{~m}^{2}$ [9]. For this reason, El Chichón has been the most studied volcano of the CVB in terms of hydrology, geothermal potential, geophysics and geological evolution [10-16].

It is known that metals in crater lakes are related to volcanic emissions, as there is a high presence of heavy metals, such as $\mathrm{Fe}, \mathrm{Pb}, \mathrm{Cu}, \mathrm{Zn}, \mathrm{Cd}, \mathrm{Hg}$ and $\mathrm{Al}$, as well as non-metallic elements such as $\mathrm{As}, \mathrm{Li}$, and $\mathrm{B}$ [17-20]. These metals can be related to the metabolic activity of the microorganisms present in these extreme environments [2, 21]. Recently, the diversity and abundance of bacteria present in the sediments of El Chichón volcano lake was reported [21]. However, there are no reports on the variation in heavy metal content in sediment and soil in and around the crater lake. Thus, the objective of this study was to analyze the changes in levels of heavy metal in sediment and soil in El Chichón crater lake volcano in the years 2015 and 2017.

\section{Materials and Methods}

El Chichón volcano is located in the mountainous region northeast of the state of Chiapas, Mexico, with coordinates $17^{\circ} 21^{\prime} 31.0^{\prime \prime} \mathrm{N}-93^{\circ} 13^{\prime} 39.9^{\prime \prime} \mathrm{W}$. This system forms part of the CVB. El Chichón is a stratified volcano with a maximum elevation of $1100 \mathrm{~m}$ a.s.l. [16, 21]. After the eruptive process in 1982, a crater lake was formed in its interior, with an estimated area of approximately $1.4 \times 10^{5} \mathrm{~m}^{2}[22,23]$. The geochemical composition, shape and depth of the crater lake have been changing continuously since its formation [10]. Temperatures ranges between 43 and $95^{\circ} \mathrm{C}$ and $\mathrm{pH}$ values are between 2 and 6 [21].

\section{Sampling of Volcanic Sediments and Soil}

Samples of volcanic sediment, crater lake and soil were collected from the periphery of the lake in 2015 and 2017 (Fig. 2). The samples were collected in triplicates and were placed in $50 \mathrm{~mL}$ sterile conical tubes. In order to preserve the sample integrity, samples were flash-frozen in liquid nitrogen. These were later stored and transported to the Molecular Biology laboratory, where they were kept at $-80^{\circ} \mathrm{C}$ until use [21].

\section{Physicochemical Characterization and Heavy Metals Determination}

Temperature and $\mathrm{pH}$ were measured in situ with the HACH multiparameter model HI-98128 (Merck, Kenilworth, NJ, U.S.A.), according to the procedure described by Rincón-Molina et al. (2019) [21].

\section{Heavy Metals Determination}

Sediment and soil samples were dried under vacuum for 24 hours at $40^{\circ} \mathrm{C}$ at a pressure of $0.05 \mathrm{MPa}$ in a JEIO-TECH oven. Subsequently, the samples were crushed to a particle diameter of $0.049 \mathrm{~mm}$. After size homogenization, acid digestion of soils and sediments were carried out by using Method 3050B reported by the EPA (Environmental Protection Agency). Briefly, $300 \mathrm{mg}$ of each sample were treated with $9 \mathrm{ml}$ of $\mathrm{HNO}_{3}, 1 \mathrm{~mL}$ of $\mathrm{H}_{2} \mathrm{O}_{2}$ and $1 \mathrm{~mL}$ of $\mathrm{HCl}$, then heated to reflux at $180^{\circ} \mathrm{C}$ for 2 hours in order to achieve total oxidation of organic matter. Heavy and total metals were measured by inductively coupled plasma-optical emission spectrometry (ICP-OES) on an Optima 7000 PerkinElmer spectrometer [24, 25]. All metallic element analyses were recorded as averages of triplicate measurements.

\section{Statistical Analysis}

The significant differences between the physicochemical characteristics of the sediments were determined by means of Analysis of Variance (ANOVA), which was performed with the software StatGraphic Centurion (version 16.1.18) For the multifactorial analysis of heavy metals, the Rstudio statistical development environment was used [26].

\section{Results and Discussion}

El Chichón volcano is a mountain with a welldefined geomorphological structure with variable 
Table 1. Description and characteristics of the study samples.

\begin{tabular}{|c|c|c|c|c|}
\hline Name & Sampling date & Geographic Localization & Temperature & $\mathrm{pH}$ \\
\hline Sediment 1 & Feb. 15 & $\begin{array}{l}17^{\circ} 21^{\prime} 32.79^{\prime \prime} \mathrm{N} \\
93^{\circ} 13^{\prime} 40.30^{\prime \prime} \mathrm{O}\end{array}$ & $50^{\circ} \mathrm{C}$ & 5.8 \\
\hline Sediment 2 & Feb. 15 & $\begin{array}{l}17^{\circ} 21^{\prime} 34.28^{\prime \prime} \mathrm{N} \\
93^{\circ} 13^{\prime} 39.26^{\prime \prime} \mathrm{O}\end{array}$ & $65^{\circ} \mathrm{C}$ & 5.5 \\
\hline Sediment 3 & Feb. 15 & $\begin{array}{l}17^{\circ} 21^{\prime} 36.81^{\prime \prime} \mathrm{N} \\
93^{\circ} 13^{\prime} 39.03^{\prime \prime} \mathrm{O}\end{array}$ & $90^{\circ} \mathrm{C}$ & 5.1 \\
\hline Sediment 4 & Feb. 15 & $\begin{array}{l}17^{\circ} 21^{\prime} 39.23^{\prime \prime} \mathrm{N} \\
93^{\circ} 13^{\prime} 39.34^{\prime \prime} \mathrm{O}\end{array}$ & $92^{\circ} \mathrm{C}$ & 2.9 \\
\hline Sediment 1 & Feb. 17 & $\begin{array}{l}17^{\circ} 21^{\prime} 33.77^{\prime \prime} \mathrm{N} \\
93^{\circ} 13^{\prime} 39.50^{\prime \prime} \mathrm{O}\end{array}$ & $65^{\circ} \mathrm{C}$ & 5.1 \\
\hline Soil 1 & Feb. 15 & $\begin{array}{l}17^{\circ} 21^{\prime} 30.14^{\prime \prime} \mathrm{N} \\
93^{\circ} 13^{\prime} 38.70^{\prime \prime} \mathrm{O}\end{array}$ & $28^{\circ} \mathrm{C}$ & 6.1 \\
\hline Soil 2 & Feb. 15 & $\begin{array}{l}17^{\circ} 21^{\prime} 30.64^{\prime \prime} \mathrm{N} \\
93^{\circ} 13^{\prime} 38.76^{\prime \prime} \mathrm{O}\end{array}$ & $30^{\circ} \mathrm{C}$ & 6.5 \\
\hline Soil 1 & Feb. 17 & $\begin{array}{l}17^{\circ} 21^{\prime} 31.86^{\prime \prime} \mathrm{N} \\
93^{\circ} 13^{\prime} 37.89^{\prime \prime} \mathrm{O}\end{array}$ & $28^{\circ} \mathrm{C}$ & 6.0 \\
\hline
\end{tabular}

hydrothermal manifestations over time, which are dependent on natural climatic and magmatic activities. This study surveys the current scenario of changes presented in physicochemical characteristics, which highlights the importance in establishing good safety practices and environmental impact monitoring.

\section{Samples and in situ Parameters}

In 2015, four sediment samples and two soil samples were collected. Two years later (2017), one sediment sample and one soil sample were collected from the same study site. The main physicochemical parameters of these samples are shown in Table 1.

The temperature values in the soil ranged from 28 to $30^{\circ} \mathrm{C}$ between study years. The highest temperatures were found in sediment samples, which ranged between $50-92^{\circ} \mathrm{C}$ for 2015 and with a mean value of $65^{\circ} \mathrm{C}$ for 2017. The volcanic activity at El Chichón volcano in
1985 gave rise to the formation of a hydrothermal lake $[9,16,22]$, rich in sulfur $[10,27]$. Sediment 1 had an increase of $15^{\circ} \mathrm{C}$, as compared to previous years. This may be due to an increase in volcanic activity and greater abundance of sulfur species, which are widely related to the $\mathrm{pH}$ values of this study, which were slightly more acidic [10, 16, 22].

The temperature in the soil remained constant. However, the temperature corresponding to sediments presented variability. The changes are related to volcanic and hydrothermal manifestations of El Chichón volcano, which may be related to temperature variations, depending on the study year. It was observed that there is no difference among $\mathrm{pH}$ values in soil according to the year of study. However, there are slight variations in the $\mathrm{pH}$ of soils 1 and 2 studied in 2015. This may be due to the presence of metals and ions in these soils that are found in different geographical locations of the El Chichón volcano. a)

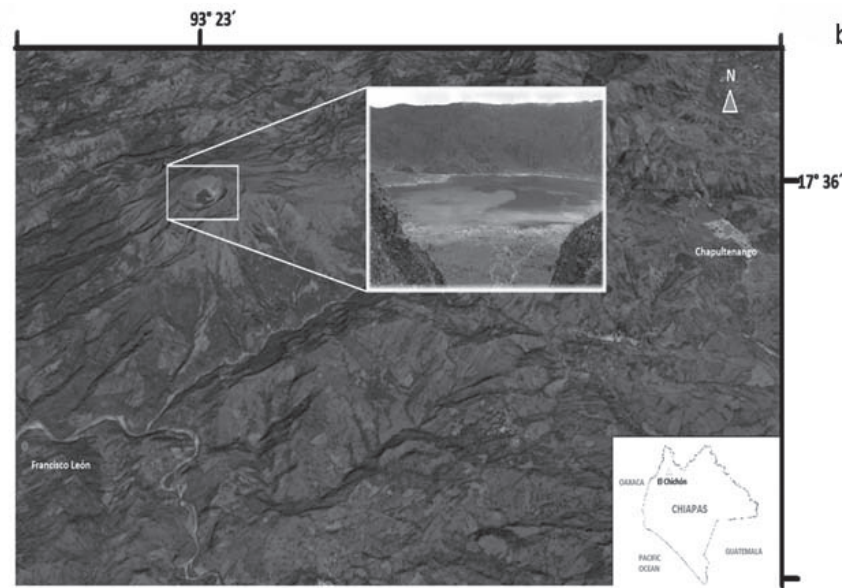

b)

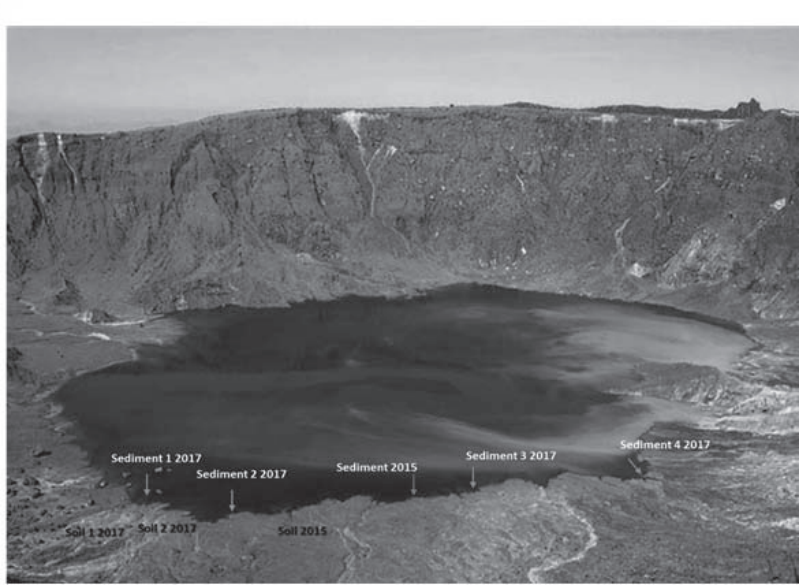

Fig. 1. Geographic localization of study site. a) El Chichón active volcano. b) Samples collected in 2015 and 2017. 


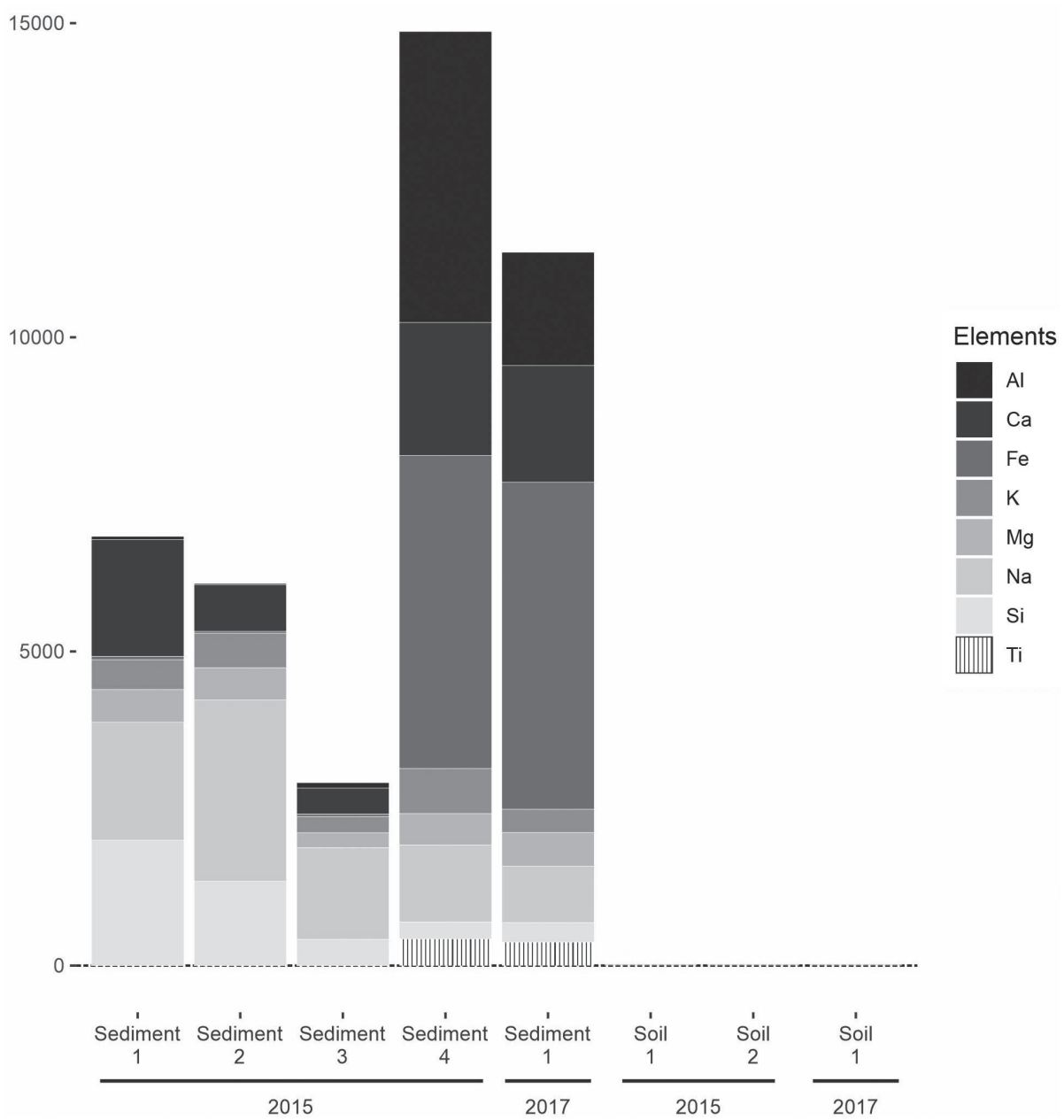

Fig. 2. Heavy metals more abundant in samples of the active volcano the El Chichón.

The sediments of El Chichón crater lake showed the lowest $\mathrm{pH}$ values, due to redox transformations of sulfur compounds. The difference found in sediment 4 was evident, as it has a greater amount of dissolved metals in addition to $\mathrm{S}$ ions. This sediment also showed the highest temperature determined in this study, as it is located near the area of greatest volcanic activity (Fig. 1). Thus, this is one of the samples originating from a most extreme location.

Lakes that are related to active volcanoes provide information about changes in volcanic activity. Consequently, these have been used as a monitoring system for water chemistry and sediment composition $[9,10]$. Such lakes are acidic by nature and have high concentrations of metals $[9,10]$.

\section{Heavy Metals of El Chichón Volcano}

The chemical composition of crater lakes can be determined by volcanic activity (mainly by the entrance of volcanic gas). These studies can take place either before or after the eruptions occur [9]. The chemical composition is a key point for evaluating the contamination of acidic soils found within the crater lake and near the agricultural and livestock soils of the region in Chiapas, Mexico. The results of HM concentrations in the sediments from El Chichón volcano are shown in Table 2 and Figs 3-4. The concentrations of heavy metals did not show statistically significant differences between 2015 and 2017. However, for most results, this helps in demonstrating that the HM concentration is related to the type of sample, either sediment or soil.

The most abundant metals were $\mathrm{Al}, \mathrm{Ca}, \mathrm{Fe}, \mathrm{Na}$, which were found in concentrations higher than $5000 \mathrm{ppm}$ in sediments (Fig. 2). This contrasted with results pertaining to soil samples, where lower heavy metal concentrations values were found. On the other hand, the less abundant heavy metals were $\mathrm{Ba}, \mathrm{Li}$, $\mathrm{Tl}$, whereby a congruent difference between volcanic sediments of the crater lake and the soil of El Chichón volcano was found (Fig. 3). In this study, the most abundant elements were $\mathrm{Fe}, \mathrm{Na}, \mathrm{Si}, \mathrm{Ca}, \mathrm{K}$ and $\mathrm{Al}$, which have been found in similar concentrations since the formation of the crater lake [16]. The concentrations of $\mathrm{Ca}, \mathrm{Si}$, and $\mathrm{Fe}$ are controlled by the solubility of some minerals such as anhydrite, cristobalite or tridymite [22]. $\mathrm{Na}, \mathrm{Ca}, \mathrm{K}$ and $\mathrm{Mg}$ have been reported in high concentrations, mainly in ionic form [9, 11, 27]. A spring called "Soap Pool" strongly influences the chemistry of the lake [11]. 


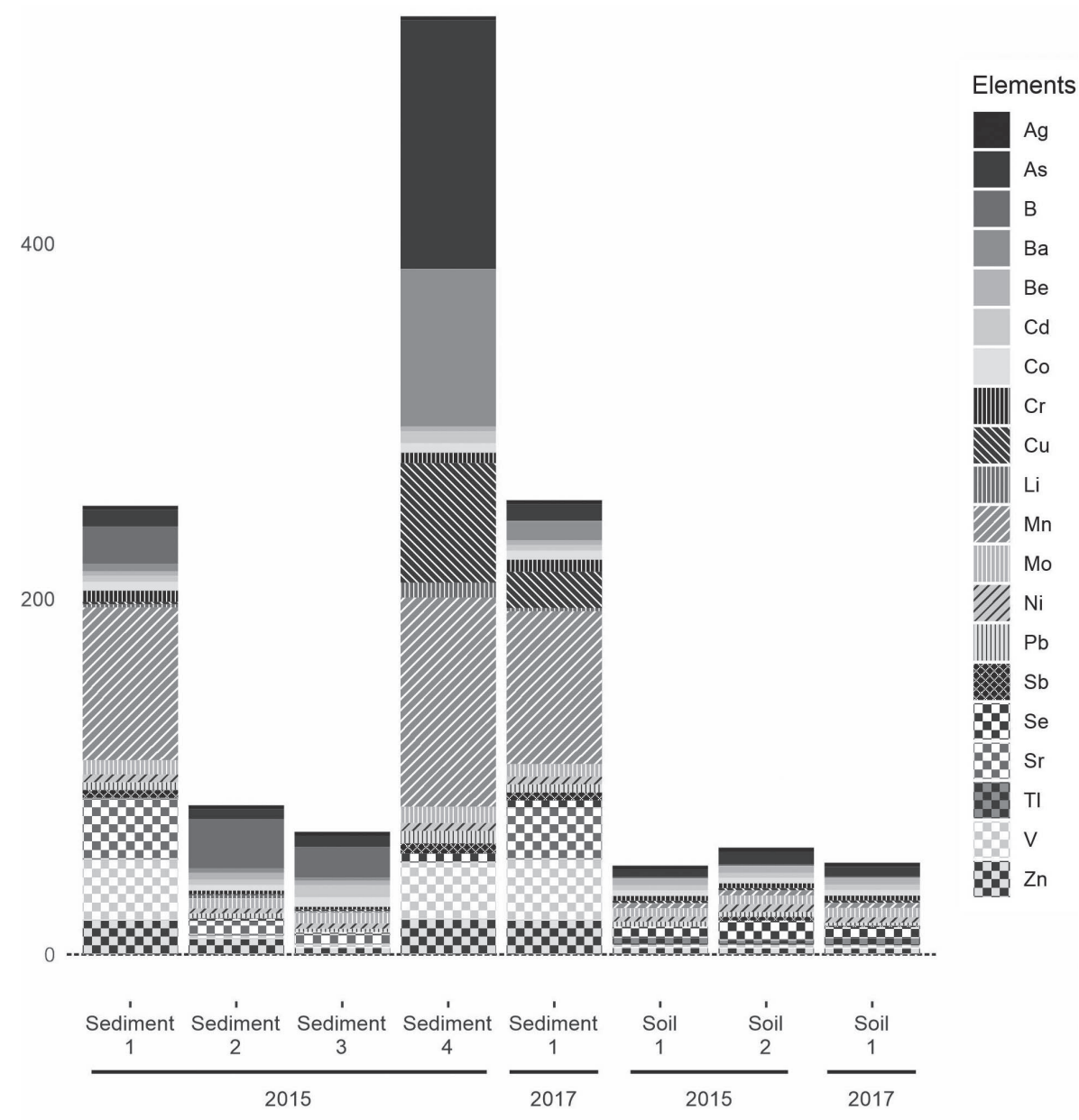

Fig. 3. Heavy metals less abundant in samples of the active volcano the El Chichón.

On the other hand, concentrations of $\mathrm{Na}, \mathrm{K}, \mathrm{Li}$ and $\mathrm{B}$ are strongly related to hydrothermal contributions to the lake, as found in other acidic crater lakes, such as Mount Pinatubo [28]. According to Cuoco et al. (2013) [11], mineral saturation could play a key role in the spread of some element concentrations, such as boron, aluminum, strontium and barium. Thus, water-rock interactions (igneous rocks, mainly) have been reported in El Chichón crater lake [9, 11, 27]. This process may leach silica and metal cations such as $\mathrm{Mg}^{2+}, \mathrm{Sr}$ and $\mathrm{Ba}$, which have been usually detected in high concentrations in this system [11]. Moreover, this interaction involves an oversaturation of magnesium and magnesium silicate minerals [9].

According to the variance in all samples the PCA, the proportion of variance was explained by the first two principal components (PC), which was approximately $80 \%$. Variables such as $\mathrm{Ag}, \mathrm{Be}, \mathrm{Ca}, \mathrm{Co}, \mathrm{Cr}, \mathrm{Cd}, \mathrm{Li}$, $\mathrm{Pb}, \mathrm{Ni}, \mathrm{Sb}, \mathrm{Mn}, \mathrm{Mo}, \mathrm{V}, \mathrm{Zn}$ have the highest loading in PC1, which accounts for about $60.3 \%$ of the total variance. On the other hand, $\mathrm{Al}, \mathrm{B}, \mathrm{Na}, \mathrm{Se}, \mathrm{Si}, \mathrm{Sr}$ have the highest loading values for PC2, and explain 19.7\% of variance (Fig. 4). In high-temperature spots, higher concentrations of metals such as $\mathrm{Al}, \mathrm{As}, \mathrm{Ba}, \mathrm{Ca}, \mathrm{Cr}, \mathrm{Cu}$, $\mathrm{Fe}, \mathrm{Li}, \mathrm{Mn}, \mathrm{Mo}$ were found. Contrary to this finding, metals such as $\mathrm{Be}, \mathrm{Se}, \mathrm{Tl}, \mathrm{Ag}, \mathrm{Na}, \mathrm{Si}, \mathrm{Sr}$ were more dominant in low temperature conditions. All metals are grouped by temperature.

Iron is an abundant element ever since the formation of the crater lake [22]. The Fe concentrations are controlled by dissolution-precipitation reactions, because of oversaturation of goethite. Because of this, the mineral has been obtained in many samples after 1983. This reaction is $\mathrm{pH}$-dependent, as seen in Eq. 1 [29]:

$$
\mathrm{Fe}_{3}^{+}+2 \mathrm{H}_{2} \mathrm{O} \leftrightarrow \mathrm{FeO} \mathrm{OH}+3 \mathrm{H}^{+}
$$

Silicon is a characteristic element of volcanic environments. In the crater lake of El Chichón volcano, it has been mostly found in the form of silica minerals $[9,11,22]$. The high concentrations of $\mathrm{Si}$ as an element are related to the degree of saturation of $\mathrm{SiO}_{2}$ as amorphous silica, quartz and chalcedony. Water-rock interactions, such as silica mineral hydrolysis, play a key role in Si concentration. This phenomenon buffers the acidity derived from dissolution of hydrothermal gases [11].

The chemical characterization of El Chichón crater lake has occurred mainly in water samples. However, 


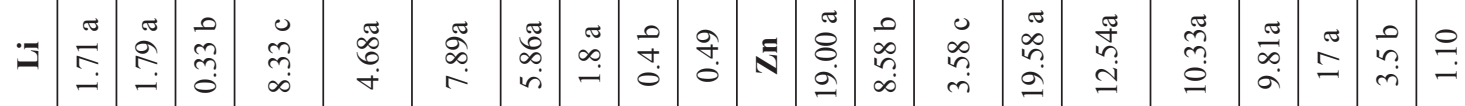

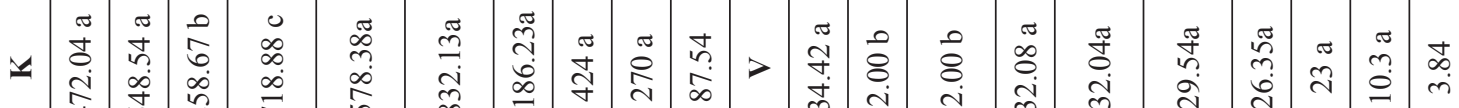
卉

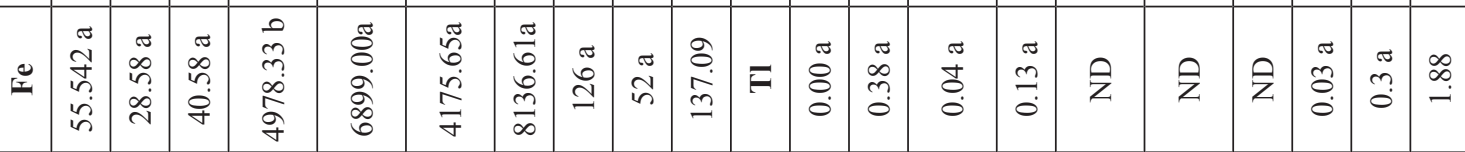

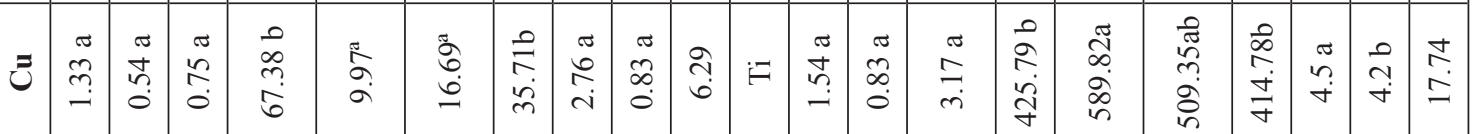

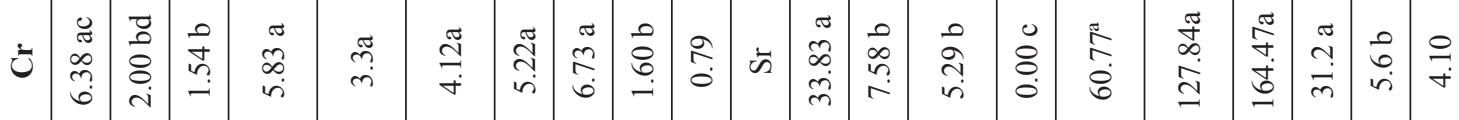

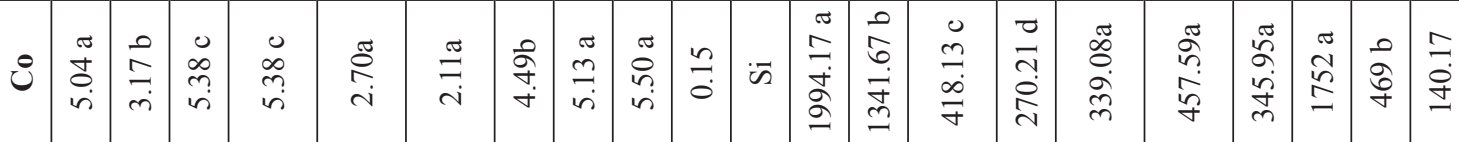

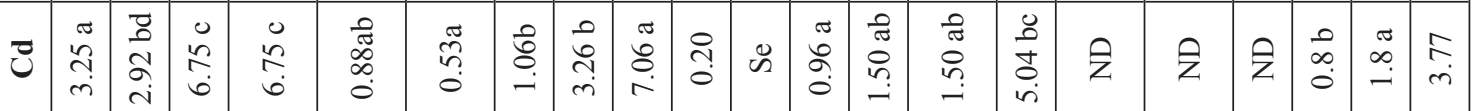

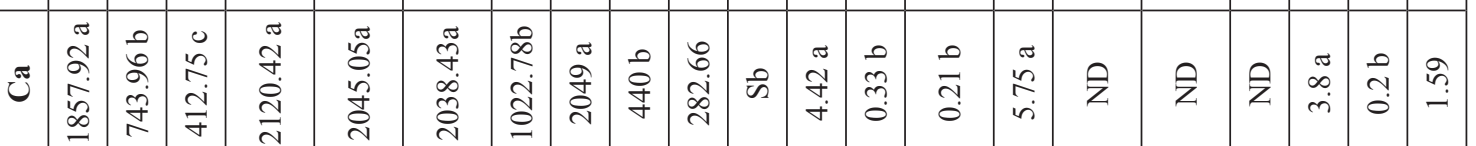

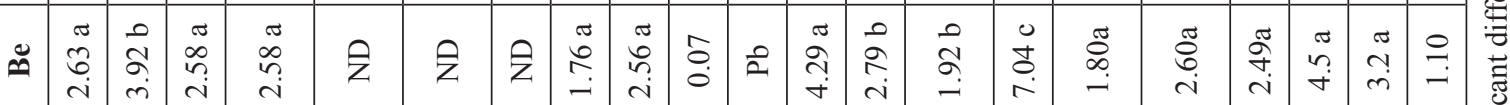

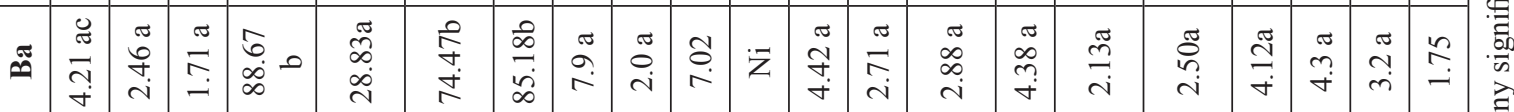

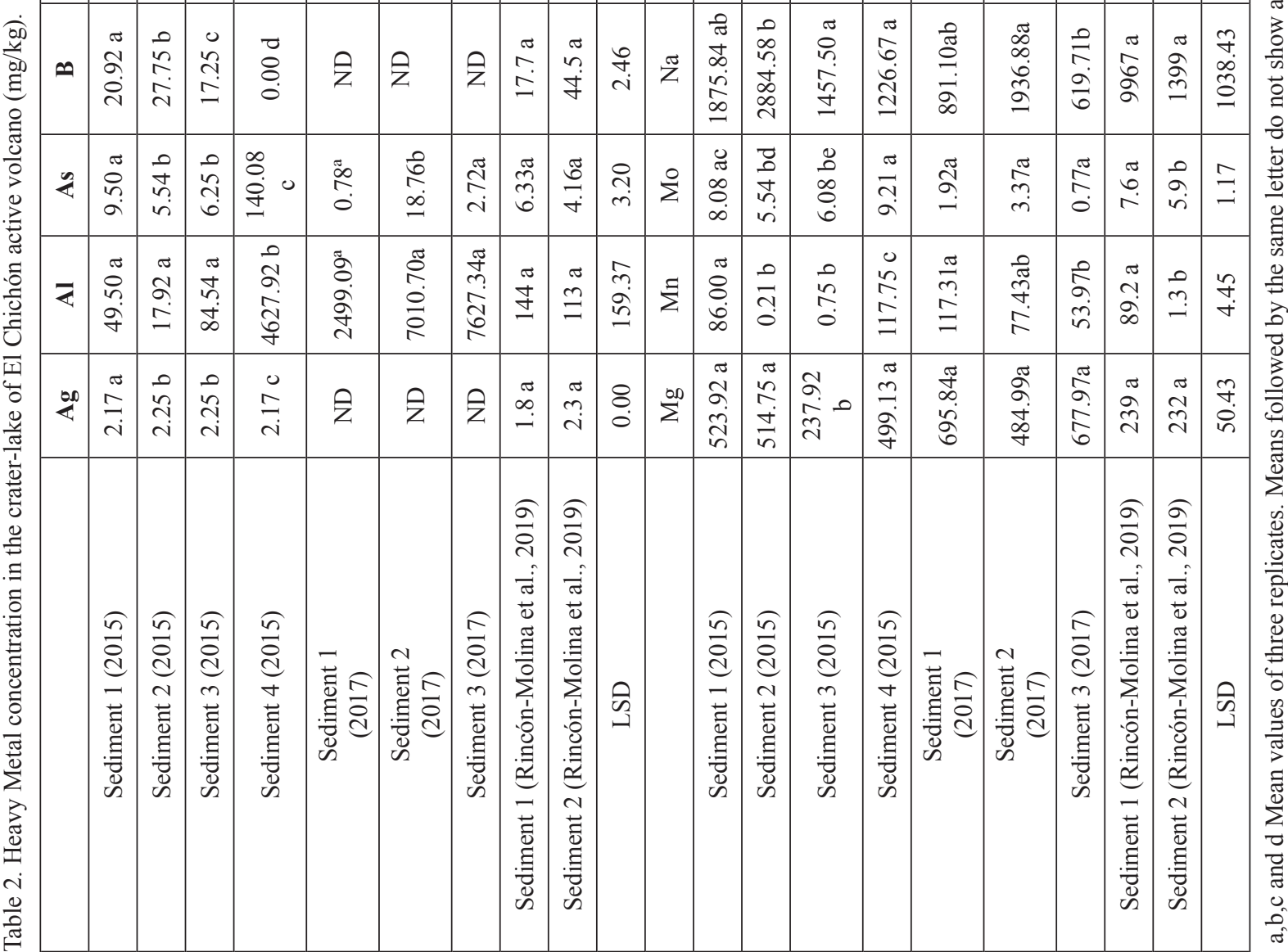




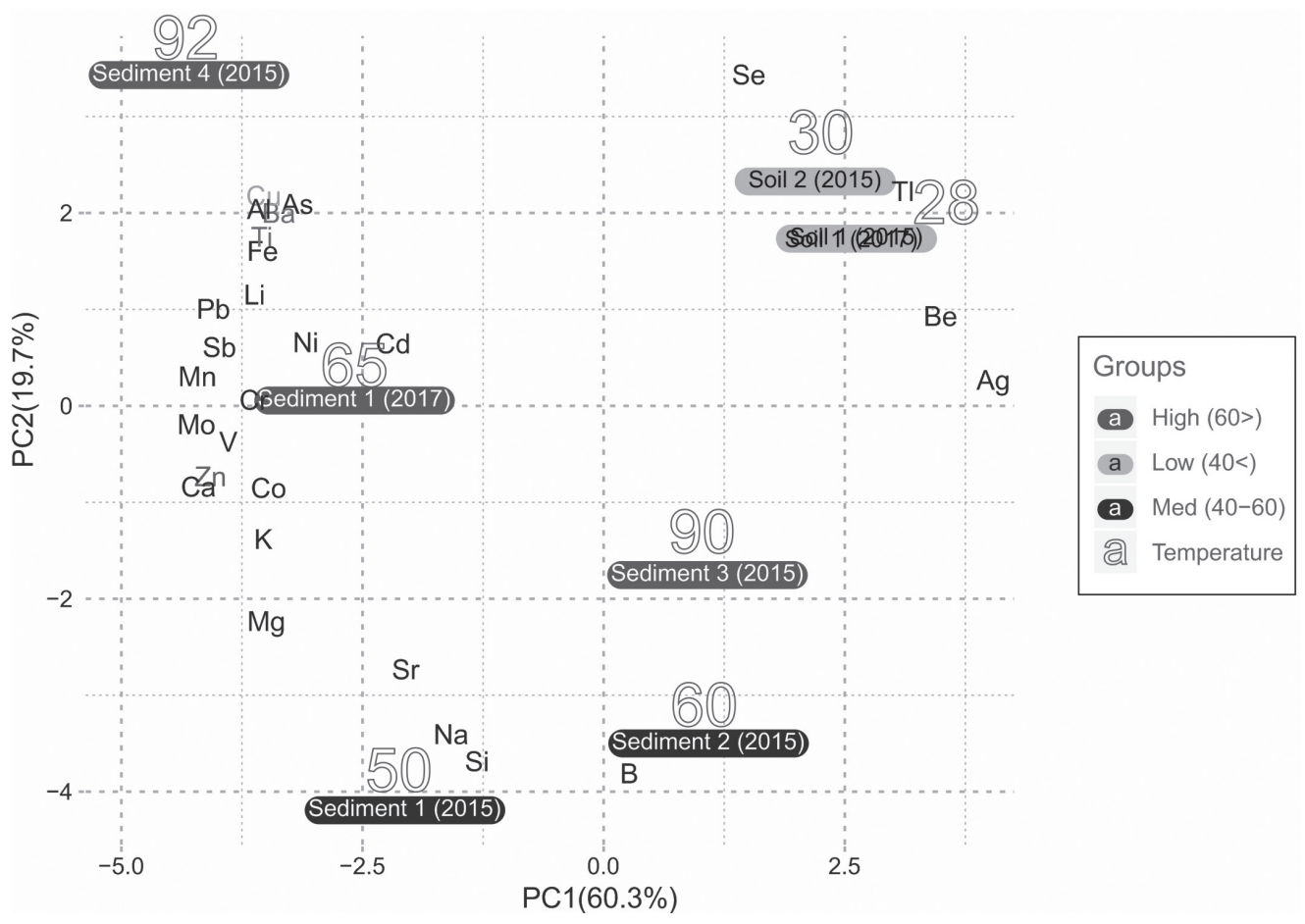

Fig. 4. Principal Component Analysis (PCA) of heavy metals more abundant in samples of the active volcano El Chichón samples.

after the eruption, the sediments from the lake contained the same silicate minerals as the rocks from the 1982 pyroclastic deposits [22].

All processes deriving from volcanic activity, such as rock-water interactions, are involved in the formation of a broad range of chemical elements, including toxic elements such as heavy metals $[9,11,21$, 30]. Thus, the toxicity would be restricted to the lake if water remains inside the crater [30]. However, the distribution of heavy metals and other toxic components occurs via other processes such as water seepage into surface or groundwater. This way, acidic craterlakes can become a source of environmental pollution $[31,32]$. This phenomenon may be occurring in El Chichón crater lake, as seepage through the crater floor has been detected, and multiple orifices or seepages from walls of altered rocks have been foIn this study, As and $\mathrm{Cd}$ were the most toxic heavy metals. Toxicity for human health and plant growth could be potentially expected from these metals. Geothermal fluids have high concentrations of arsenic. For instance, there is evidence of concentration of As in volcanic fluids and geothermal systems in some places in Latin America. Common sources of As in volcanic environments are arsenic-rich reservoir rocks (including the rocks of the volcanic edifices) and volcanic gases emitted in plumes and fumaroles [33]. Likewise, Northern Chile has presented arsenic pollution from volcanic sources because the release of As from rocks into geothermal fluids occurs predominantly along the boundaries of active tectonic plates [34]. It is common to find high levels of this element in volcanic environments. The presence of arsenic in this system could be a source of pollution due to water seepage, as described earlier.

Arsenic (As) has been widely studied due to its high toxicity [20,35]. According to the World Health Organization (WHO), this element is linked to toxicity for human health due to the formation of dermal lesions, peripheral neuropathy, skin cancer, bladder and lung cancers and peripheral vascular disease. Recently, several studies have shown that there is a closer relationship between exposure to arsenic and the risk of developing diseases such as cancer, cardiovascular events, diabetes and metabolic disorders [36]. There is also evidence that water intake containing $0.06-0.86 \mathrm{mg} / \mathrm{L}$ can cause respiratory and pulmonary diseases [37].

El Chichón active volcano has concentrations of As ranging from 4.21 to $140 \mathrm{mg} / \mathrm{L}$. In other lakes of volcanic origin, concentrations of $\mathrm{As}$ and $\mathrm{B}$ are highly correlated. This correlation, along with high $\mathrm{CO}_{2}$ emissions (evidenced in "El Chichón" crater lake) suggest the leaching of sediments. This phenomenon has been proposed as a mechanism for increasing arsenic concentration in waters [38].

All of these concentrations of As have been evaluated in other studies, which is alarming due to the risk of toxicity and harmful effects to health $[36,37$, 39].

On the other hand, Cadmium $(\mathrm{Cd})$ is a toxic transition metal, which is considered as one of the five most hazardous environmental contaminants by the Agency for Toxic Substances and Disease Registry. Cadmium is considered highly toxic and bioaccumulates progressively in the organism [40]. Exposure to $\mathrm{Cd}$ 
in animals and humans has toxic effects on various organs and tissues, such as liver, kidney, lung, gut, central nervous system, ovaries, testes, and pancreas [41]. Regarding plants, $\mathrm{Cd}$ can produce a toxic effect with amounts as low as $0.2 \mathrm{nM}$ [42]. Because of the above, the exposure and propagation of cadmium can be a factor of environmental risk and serious health issues.

This study suggests that El Chichón crater lake could be an important source of toxic elements. However, it would be important to carry out a study about element speciation and evaluate if water seepage could contaminate water bodies outside of the crater lake. Geothermal fluids with high concentrations of trace and toxic elements may have surface manifestations which can pollute rivers and groundwater near these sites. Sites with a direct connection to these effluents can also be potentially contaminated [43]. Hydrographic studies from El Chichón volcano confirm that the hydrographic system is not isolated and is interconnected with different rivers around the volcano, as reported by Taran and Peiffer (2008). These results indicated that Río Magdalena is the only drainage of all thermal waters discharged from the slopes of the volcano.

\section{Conclusions}

The concentrations of heavy metals did not show statistically significant differences between 2015 and 2017. However, in most results they allow us to demonstrate that the concentration of heavy metals was related to the type of sample, either sediment or soil. Also, this study suggests that El Chichón crater lake could be an important source of toxic elements, such as As and Cd. Thus, it would be important to carry out a study on the distribution and speciation of elements and to assess whether water seepage could contaminate water bodies, such as rivers and lagoons outside of the crater lake. Studies regarding concentrations of heavy metals in agricultural soils of the region would be of equal importance.

\section{Acknowledgements}

This research was supported by Project 'CB-2015253281' 'Consejo Nacional de Ciencia y Tecnología' (CONACyT, Mexico) and Project No. 8216.20-P 'Tecnológico Nacional de Mexico' (TecNM, México). We would like to thank CONACyT for the doctoral fellowship assigned to Betsy A. Peña-Ocaña (No. 465358). Finally, C.I. O.-O. and I.O V.-R received grantaided support from CONACyT.

\section{Conflict of Interest}

The authors declare no conflict of interest

\section{References}

1. MASON E., EDMONDS M., LIU E., JENNER F. Metals emissions at arc volcanoes. 20th EGU General Assembly, EGU2018, Proceedings from the conference held 4-13 April, 2018 in Vienna, Austria, 20, 8861, 2018.

2. MEDRANO-SANTILLANA M., SOUZA-BRITO E.M., DURAN R., GUTIERREZ-CORONA F., REYNA-LÓPEZ G.E. Bacterial diversity in fumarole environments of the Paricutín volcano, Michoacán (Mexico). Extremophiles, 21 (3), 499, 2017.

3. MA Q., HAN L., ZHANG J., ZHANG Y., LANG Q., LI F., HAN A., BAO Y., LI K., ALU S. Environmental risk assessment of metals in the volcanic soil of Changbai mountain. International Journal of Environmental Research and Public Health, 16 (11), 2019.

4. MAPELLI F., MARASCO R., ROLLI E., DAFFONCHIO D., DONACHIE S., BORIN S. Microbial Life in Volcanic Lakes. In Advances in Volcanology (pp. 507-522). Springer. 2015.

5. ARCE J.L., WALKER J., KEPPIE J.D. Petrology of two contrasting Mexican volcanoes, the Chiapanecan (El Chichón) and Central American (Tacaná) volcanic belts: the result of rift- versus subduction-related volcanism. International Geology Review, 56 (4), 501, 2014.

6. MANEA M., MANEA V.C. On the origin of El Chichón volcano and subduction of Tehuantepec Ridge: A geodynamical perspective. Journal of Volcanology and Geothermal Research, 175 (4), 459, 2008.

7. VERMA S.P., VERMA S.K. Petrogenetic and tectonic implications of major and trace element and radiogenic isotope geochemistry of Pliocene to Holocene rocks from the Tacaná Volcanic Complex and Chiapanecan Volcanic Belt, southern Mexico. Lithos, 312-313, 274, 2018.

8. VARLEY N. Volcanoes volcano of Mexico volcano of Mexico. In Encyclopedia of Sustainability Science and Technology (pp. 11613-11633). New York, NY: Springer New York. 2012.

9. ARMIENTA M.A., VILACLARA G., DE LA CRUZREYNA S., RAMOS S., CENICEROS N., CRUZ O., AGUAYO A., ARCEGA-CABRERA F. Water chemistry of lakes related to active and inactive Mexican volcanoes. Journal of Volcanology and Geothermal Research, 178 (2), 249, 2008.

10. CASAS A.S., ARMIENTA M.A., RAMOS S. Sulfur speciation with high performance liquid chromatography as a tool for El Chichón volcano, crater lake monitoring. Journal of South American Earth Sciences, 72, 241, 2016.

11. CUOCO E., DE FRANCESCO S., TEDESCO D. Hydrogeochemical dynamics affecting steam-heated pools at El Chichón Crater (Chiapas - Mexico). Geofluids, 13 (3), 331, 2013

12. SCOLAMACCHIA T., DINGWELL D.B. Sulfur as a binding agent of aggregates in explosive eruptions. Bulletin of Volcanology, 76 (10), 2014.

13. JÁCOME PAZ M.P., TARAN Y., INGUAGGIATO S., COLLARD N. $\mathrm{CO}_{2}$ flux and chemistry of El Chichón crater lake (México) in the period 2013-2015: Evidence for the enhanced volcano activity. Geophysical Research Letters, 43 (1), 127, 2016.

14. CISNEROS DE LEÓN A., SCHMITT A.K. Intrusive reawakening of El Chichón volcano prior to its Holocene eruptive hyperactivity. Journal of Volcanology and Geothermal Research, 377, 53, 2019. 
15. PEIFFER L., ROUWET D., TARAN Y. Fluid Geochemistry of El Chichón Volcano-Hydrothermal System (pp. 77-95). Springer, Berlin, Heidelberg. 2015.

16. TARAN Y.A., PEIFFER L. Hydrology, hydrochemistry and geothermal potential of El Chichón volcanohydrothermal system, Mexico. Geothermics, 38 (4), 370, 2009.

17. HENLEY R.W. Hyperacidic volcanic lakes, metal sinks and magmatic gas expansion in arc volcanoes. In Volcanic Lakes (pp. 155-178). Springer, Berlin, Heidelberg. 2015.

18. PACK B., SCHMITT A.K., ROBERGE J., TENORIO F.G., DAMIATA B.N. Zircon xenocryst resorption and magmatic regrowth at El Chichón Volcano, Chiapas, Mexico. Journal of Volcanology and Geothermal Research, 311, 170, 2016.

19. MARCOVECCHIO J.E., SE BOTTÉ R.F. Heavy Metals, Major Metals, Trace Elements. In L.M.L. Nollet (Ed.), Handbook of Water AnalysisEdition (2a Ed., pp. 273-210). Florida (USA): CRC Press, Taylor \& Francis Group LCC, Boca Ratón. 2007.

20. VAREKAMP J.C. The chemical composition and evolution of volcanic lakes. In Volcanic Lakes (pp. 93123). Springer, Berlin, Heidelberg. 2015.

21. RINCÓN-MOLINA C.I., HERNÁNDEZ-GARCÍA J.A., RINCÓN-ROSALES R., GUTIÉRREZ-MICELI F.A., RAMÍREZ-VILLANUEVA D.A., GONZÁLEZTERREROS E., PEÑA-OCAÑA B.A., PALOMEQUEDOMÍNGUEZ H., LUC DENDOOVEN, RUÍZVALDIVIEZO V.M. Structure and Diversity of the Bacterial Communities in the Acid and Thermophilic Crater-Lake of the Volcano "El Chichón", Mexico. Geomicrobiology Journal, 1, 2019.

22. CASADEVALL T.J., DE LA CRUZ-REYNA S., ROSE W.I., BAGLEY S., FINNEGAN D.L., ZOLLER W.H. Crater lake and post-eruption hydrothermal activity, El Chichón Volcano, Mexico. Journal of Volcanology and Geothermal Research, 23 (1-2), 169, 1984.

23. MACÍAS J.L., CAPRA L., ARCE J.L., ESPÍNDOLA J.M., GARCÍA-PALOMO A., SHERIDAN M.F. Hazard map of El Chichón volcano, Chiapas, México: Constraints posed by eruptive history and computer simulations. Journal of Volcanology and Geothermal Research, 175 (4), 444, 2008.

24. GONZÁLEZ-TERREROS E., RUIZ-VALDIVIEZO V., GALVÁN-VELÁZQUEZ A., FRANCO-HERNÁNDEZ M., LUNA-GUIDO M., DENDOOVEN L. Heavy Metals in Mine-Tailing Soil Mixtures Cultivated with Ricinus communis L. Polish Journal of Environmental Studies, 27 (5), 2007, 2018.

25. JAVED T., AHMAD N., MASHIATULLAH A. Heavy Metals Contamination and Ecological Risk Assessment in Surface Sediments of Namal Lake, Pakistan. Polish Journal of Environmental Studies, 27 (2), 675, 2018.

26. ALONSO CASTILLO M.L., SÁNCHEZ TRUJILLO I., VEREDA ALONSO E., GARCÍA DE TORRES A., CANO PAVÓN J.M. Bioavailability of heavy metals in water and sediments from a typical Mediterranean Bay (Málaga Bay, Region of Andalucía, Southern Spain). Marine Pollution Bulletin, 76 (1-2), 427, 2013.

27. SARKAR D.R graphics. Handbook of Statistics, 32, 49, 2014.

28. ARMIENTA M.A., DE LA CRUZ-REYNA S., RAMOS S., CENICEROS N., CRUZ O., AGUAYO A., ARCEGACABRERA F. Hydrogeochemical surveillance at El Chichón volcano crater lake, Chiapas, Mexico. Journal of Volcanology and Geothermal Research, 285, 118, 2014.
29. STIMAC J.A., GOFF F., COUNCE D., LAROCQUE A.C.L., HILTON D.R., MORGENSTERN U. The crater lake and hydrothermal system of Mount Pinatubo, Philippines: evolution in the decade after eruption. Bulletin of Volcanology, 66 (2), 149, 2004.

30. VAN HINSBERG V., VIGOUROUX N., PALMER S., BERLO K., MAURI G., WILLIAMS-JONES A., FISCHER T. Element flux to the environment of the passively degassing crater lake-hosting KawahIjen volcano, Indonesia, and implications for estimates of the global volcanic flux. Geological Society, London, Special Publications, 437 (1), 9, 2017.

31. LÖHR A.J., BOGAARD T.A., HEIKENS A., HENDRIKS M. R., SUMARTI S., VAN BERGEN M.J., VAN GESTEL K., VAN STRAALEN N., VROON P., WIDIANARKO B. Natural pollution caused by the extremely acidic crater lake KawahIjen, East Java, Indonesia. Environmental science and pollution research international, 12 (2), 89. Retrieved from http://www.ncbi.nlm.nih.gov/pubmed/15859115. 2005.

32. DELMELLE P., BERNARD A. Geochemistry, mineralogy, and chemical modeling of the acid crater lake of KawahIjen Volcano, Indonesia. Geochimica et Cosmochimica Acta, 58 (11), 2445, 1994.

33. SRIWANA T., VAN BERGEN M., SUMARTI S., DE HOOG J.C., VAN OS B.J., WAHYUNINGSIH R., DAM M.A. Volcanogenic pollution by acid water discharges along Ciwidey River, West Java (Indonesia). Journal of Geochemical Exploration, 62 (1-3), 161, 1998.

34. MORALES-SIMFORS N., BUNDSCHUH J., HERATH I., INGUAGGIATO C., CASELLI A.T., TAPIA J., ERLINGTTON APAZACHOQUEHUAYTA F., ARMIENTA M.A., ORMACHEA M., EROUSCILLA J., LÓPEZ D.L. Arsenic in Latin America: A critical overview on the geochemistry of arsenic originating from geothermal features and volcanic emissions for solving its environmental consequences. Science of The Total Environment, 135564. 2019.

35. BUNDSCHUH J., MAITY J.P. Geothermal arsenic: Occurrence, mobility and environmental implications. Renewable and Sustainable Energy Reviews, 42, 1214, 2015.

36. VALDÉS J., TAPIA J.S. Spatial monitoring of metals and As in coastal sediments of northern Chile: An evaluation of background values for the analysis of local environmental conditions. Marine Pollution Bulletin, 145, 624, 2019.

37. KUO C.-C., MOON K.A., WANG S.-L., SILBERGELD E., NAVAS-ACIEN A. The Association of Arsenic Metabolism with Cancer, Cardiovascular Disease, and Diabetes: A Systematic Review of the Epidemiological Evidence. Environmental Health Perspectives, 125 (8), 087001, 2017.

38. STEINMAUS C., FERRECCIO C., ACEVEDO J., BALMES J.R., LIAW J., TRONCOSO P., DAUPHINÉ C.D., NARDONE A., SMITH A.H. High risks of lung disease associated with early-life and moderate lifetime arsenic exposure in northern Chile. Toxicology and Applied Pharmacology, 313, 10, 2016.

39. LÓPEZ D.L., BUNDSCHUH J., BIRKLE P., ARMIENTA M.A., CUMBAL L., SRACEK O., CORNEJO L., ORMACHEA M. Arsenic in volcanic geothermal fluids of Latin America. Science of the Total Environment, 429, 57, 2012.

40. BARDACH A.E., CIAPPONI A., SOTO N., CHAPARRO M.R., CALDERON M., BRIATORE A., CADOPPI N., TASSARA R.,, LITTER M.I. Epidemiology of chronic 
disease related to arsenic in Argentina: A systematic review. Science of The Total Environment, 538, 802, 2015.

41. ZHANG H., REYNOLDS M. Cadmium exposure in living organisms: A short review. Science of The Total Environment, 678, 15, 761, 2019.

42. TREVIÑO S., WAALKES M.P., FLORES HERNÁNDEZ J.A., LEÓN-CHAVEZ B.A., AGUILAR-ALONSO P., BRAMBILA E. Chronic cadmium exposure in rats produces pancreatic impairment and insulin resistance in multiple peripheral tissues. Archives of Biochemistry and Biophysics, 583, 27, 2015.
43. ANDRESEN E., KAPPEL S., STÄRK H.-J., RIEGGER U., BOROVEC J., MATTUSCH J., HEINZ A., SCHMELZER C., MATOUŠKOVÁ S., DICKINSON B., KÜPPER H. Cadmium toxicity investigated at the physiological and biophysical levels under environmentally relevant conditions using the aquatic model plant Ceratophyllumdemersum. New Phytologist, 210 (4), 1244, 2016. 